\title{
Helicobacter pylori and the prevention of gastric cancer
}

\author{
Terrence Sullivan $\mathrm{PhD}^{1,2}$, Fredrick D Ashbury PhD ${ }^{2,3,4}$, Carlo A Fallone MD FRCPC ${ }^{5}$, Farah Naja MSc ${ }^{1}$, \\ Richard Schabas MD MHSC FRCPC ${ }^{6}$, Philip C Hébert MD PhD FCFPC ${ }^{7,8}$, Richard Hunt MD FRCP FRCPC 9 , \\ Nicola Jones MD FRCPC PhD ${ }^{10,11}$
}

T Sullivan, FD Ashbury, CA Fallone, et al. Helicobacter pylori and the prevention of gastric cancer. Can J Gastroenterol 2004;18(5):295-302.

BACKGROUND: Helicobacter pylori is an important cause of stomach cancer that infects a substantial proportion of the Canadian adult population. H pylori can be detected by noninvasive tests and effectively eradicated by medical treatment. Screening for and treatment of $H$ pylori may represent a significant opportunity for preventive oncology.

METHODS: Cancer Care Ontario organized a workshop held in Toronto, Ontario, on October 24 and 25, 2002, to: review the current state of knowledge regarding $\mathrm{H}$ pylori treatment and cancer prevention; determine if there is currently sufficient evidence to consider the promotion of $\mathrm{H}$ pylori treatment for the purpose of cancer prevention; identify critical areas for research; and advise Cancer Care Ontario on H pylori and cancer prevention.

RESULTS: Workshop participants developed a number of recommendations for research into the relationship between $\mathrm{H}$ pylori and stomach cancer, including determining the prevalence of infection in different regions of Canada, the pathogenetic sequence of carcinogenesis from $H$ pylori infection, and the implementation of a prospective observational study.

INTERPRETATION: Although the rate of $\mathrm{H}$ pylori infection is declining in Canada and the treatment of $\mathrm{H}$ pylori is generally accepted to be safe, the evidence to date may not warrant the implementation of population screening for $\mathrm{H}$ pylori infection to prevent gastric carcinoma in average-risk populations. Rather, a demonstration project is needed to estimate prevalence, evaluate the merits of screening, measure patient compliance and physician participation, develop education materials, establish a registry for monitoring and evaluation, and develop a quality assurance framework.

Key Words: Cancer prevention; Gastric cancer; Health promotion; Helicobacter pylori; Primary care; Stomach

\section{Le Helicobacter pylori et la prévention du cancer gastrique}

HISTORIQUE : Le Helicobacter pylori est une importante cause de cancer de l'estomac qui infecte une proportion substantielle de la population canadienne adulte. Le $H$ pylori peut être décelé à l'aide d'examens non envahissants et éradiqué par un traitement médical. Le dépistage et le traitement du $\mathrm{H}$ pylori représentent peut-être une occasion importante d'oncologie préventive.

MÉTHODOLOGIE : Cancer Care Ontario a organisé un atelier à Toronto, en Ontario, les 24 et 25 octobre 2002, afin d'évaluer l'état actuel des connaissances au sujet du traitement du H pylori pour la prévention du cancer, d'examiner s'il existe assez de données probantes pour envisager la promotion du traitement du $\mathrm{H}$ pylori pour prévenir la prévention du cancer, de repérer les secteurs critiques pour la recherche et de conseiller Cancer Care Ontario au sujet du $\mathrm{H}$ pylori et du traitement du cancer.

RÉSULTATS : Les participants à l'atelier ont élaboré plusieurs recommandations pour la recherche sur le lien entre le $\mathrm{H}$ pylori et le cancer de l'estomac, y compris la détermination de la prévalence d'infection dans diverses régions du Canada, la séquence pathogène de la carcinogenèse de l'infection au $H$ pylori et l'implantation d'une étude prospective par observation.

INTERPRÉTATION : Bien que le taux d'infection au $H$ pylori diminue au Canada et que le traitement du $\mathrm{H}$ pylori soit généralement accepté comme sûr, les données probantes jusqu'à maintenant ne justifient pas vraiment l'implantation d'un dépistage du $H$ pylori au sein de la population afin de prévenir le carcinome gastrique dans la population à risque moyen. Toutefois, un projet pilote s'impose pour évaluer la prévalence de la maladie et les avantages du dépistage, mesurer le respect du traitement par le patient et la participation du médecin et élaborer de la documentation éducative, mettre sur pied un registre de surveillance et d'évaluation ainsi qu'une structure d'assurance de la qualité.

\footnotetext{
${ }^{1}$ Division of Research and Cancer Control, Cancer Care Ontario, Toronto, Ontario; ${ }^{2}$ Department of Health Policy, Management and Evaluation, and Department of Public Health Science, University of Toronto, Toronto, Ontario; ${ }^{3}$ Department of Oncology, McGill University, Montreal, Quebec; ${ }^{4}$ PICEPS Consultants Inc, Whitby, Ontario; ${ }^{5}$ Division of Gastroenterology, McGill University, Montreal, Quebec; ${ }^{6}$ Schabas $\mathcal{E}^{2}$ Associates, Toronto, Ontario; ${ }^{7}$ Department of Family Medicine, University of Toronto, Toronto, Ontario; ${ }^{8}$ Clinical Ethics Centre, Sunnybrook and Women's College Health Sciences Centre, Toronto, Ontario; ${ }^{9}$ Department of Gastroenterology, McMaster University Medical Centre, Hamilton, Ontario; ${ }^{10}$ Research Institute, Hospital for Sick Children, Toronto, Ontario; ${ }^{11}$ Departments of Pediatrics and Physiology, University of Toronto, Toronto, Ontario

Correspondence and reprints: Dr Terrence Sullivan, Cancer Care Ontario, 620 University Avenue, Toronto, Ontario M5G 2 L7.

Telephone 416-217-1244, fax 416-217-1243, e-mail terry.sullivan@cancercare.on.ca

Received for publication September 9, 2003. Accepted March 19, 2004
} 
Oastric cancer ranks as the second leading cause of cancerJ related mortality, worldwide, after lung cancer. According to the International Agency for Research on Cancer (1), gastric cancer incidence and mortality in 2000 were 558,458 and 405,215 , respectively, for men and 317,883 and 241,352, respectively, for women.

Stomach cancer displays important geographical patterns and temporal trends. Rates are much higher in developing countries and Japan than in the developed world. Canada has relatively low rates of stomach cancer, but Newfoundland has rates about three times the national average (2). As the population ages, and with all other factors including Helicobacter pylori prevalence remaining equal, the incidence of gastric cancer is anticipated to increase (3). Currently, the outcome of treatment for stomach cancer is poor, with five-year survival rates estimated to be between 5\% to $15 \%$ (4).

Multiple steps and factors are implicated in gastric carcinogenesis, including host and environmental factors, along with the resultant chronic mucosal inflammation. Several epidemiological studies have associated $\mathrm{H}$ pylori, including $\mathrm{Cag} \mathrm{A}$-positive strains, with gastric adenocarcinoma (5-9), although certain populations in Africa have high prevalence of infection but low gastric cancer rates - a finding labelled the African enigma (10). Evidence suggests that $H$ pylori causes atrophic gastritis and intestinal metaplasia, two potential precancerous lesions (11). In 1994, the International Agency for Research on Cancer designated $H$ pylori as a group 1 human carcinogen (12).

$\mathrm{H}$ pylori is commonly acquired in childhood, usually by 10 years of age, and will persist for life unless treated (13). Transmission is believed to be primarily by direct fecal-oral and oral-oral contact with an infected person. Risk of transmission is related to standards of sanitation and hygiene. H pylori infection is also known to cluster in families (14-16). It has been estimated that approximately one-half of the world's population is infected with the $H$ pylori bacterium (17).

In Nova Scotia, the seroprevalence of this infection increased from $21 \%$ in the third decade to $50 \%$ in the eighth decade of life (18). However, there are certain populations in Canada with much higher infection rates. One study found that $95 \%$ of a First Nations community in Manitoba was infected (19), and that $67 \%$ of children from this community tested positive by two years of age (20). Prevalence studies that test across all of Canada are few and are usually not in asymptomatic individuals. The Canadian Adult Dyspepsia Empiric Treatment - Prompt Endoscopy (CADET-PE) study found that approximately $30 \%$ of dyspeptic patients were infected (21).

The results of these studies and the important limitations are summarised in Table 1.

Given the limitations of these studies, their estimates of prevalence can not be applied to the general Canadian population.

Treatment of $H$ pylori infection involves an antibiotic regimen prescribed with a proton pump inhibitor, for a period of seven to 14 days $(22,23)$. The Canadian Helicobacter Study Group recommendations for $\mathrm{H}$ pylori therapies include either $(24,25)$ :

- A twice daily, seven day regimen of a proton pump inhibitor (PPI) or ranitidine bismuth citrate (RBC) $400 \mathrm{mg}$, clarithromycin $500 \mathrm{mg}$ and amoxicillin $1000 \mathrm{mg}$; or
- A twice daily, seven day regimen of PPI or RBC, clarithromycin $500 \mathrm{mg}$ or $250 \mathrm{mg}$, and metronidazole $500 \mathrm{mg}$.

$H$ pylori is eradicated in the majority of cases, with cure rates above $80 \%$ in most Canadian studies (26-28). Compliance and antibiotic resistance remain important challenges (29-31). Treatment should be based on the community's $H$ pylori susceptibility profile. In Canada, there is a relatively high resistance rate of $\mathrm{H}$ pylori to metronidazole (20\% to $40 \%$ ) when compared with clarithromycin (less than $5 \%$ ) or amoxicillin (less than 1\%) (32).

There are important unanswered questions about the safety and practicality of $\mathrm{H}$ pylori eradication for cancer prevention. $H$ pylori eradication may represent a rare opportunity to prevent an important and devastating disease on a scale comparable to the benefits of breast or colorectal cancer screening. It was these questions which motivated an expert workshop on the topic.

\section{OBJECTIVES}

Cancer Care Ontario organized a workshop, held in Toronto, Ontario, on October 24 and 25, 2002, with the following objectives:

- To review the current state of knowledge regarding H pylori treatment and cancer prevention;

- To determine if there is currently sufficient evidence to consider promotion of $\mathrm{H}$ pylori treatment for the purpose of cancer prevention;

- To identify critical areas for research; and

- To advise Cancer Care Ontario on the nature and content of public and professional education about $\mathrm{H}$ pylori and cancer prevention.

Knowledgeable individuals with backgrounds in epidemiology, microbiology, gastroenterology, family medicine, ethics, public health and behavioural science prepared background papers on the existing evidence concerning $H$ pylori and gastric cancer prevention, and next steps for population research (Appendix A). Papers were presented on the epidemiology of $\mathrm{H}$ pylori and gastric cancer; pathogenesis of $\mathrm{H}$ pylori-mediated gastric cancers; risks and realities; program applications; and ethical issues. To facilitate participants' understanding of the key issues and preparation for the workshop discussion, these background papers were circulated to workshop attendees before the event. Workshop participants were also asked to complete a preworkshop survey (Appendix B), which was designed to elicit responses to key questions that would be used to guide the workshop discussion.

\section{QUESTIONS ADDRESSED IN THE WORKSHOP} 1. Is there sufficient evidence that $H$ pylori is an important cause of stomach cancer?

H pylori is a spiral-shaped, Gram-negative, microaerophilic rod with four to seven flagella. $H$ pylori binds to gastric mucosa through one or more receptors residing on the surface of gastric epithelial cells, underneath the mucous layer. Although $\mathrm{H}$ pylori infection is common (worldwide estimates range from $40 \%$ to $70 \%$ ), only a small proportion of infected individuals will develop complications, including peptic ulcer disease, 
TABLE 1

Prevalence of Helicobacter pylori in Canada

\begin{tabular}{|c|c|c|c|c|}
\hline Author, year, reference & Location & Number of subjects & Prevalence (\%) & Limitations \\
\hline Veldhuyzen van Zanten et al, 1994 (18) & Halifax, Nova Scotia & 316 , age: $18-72$ years & $\begin{array}{l}20,3 \text { rd decade } \\
50,8 \text { th decade }\end{array}$ & Small sample size \\
\hline Bernstein et al, 1999 (19) & Manitoba & 256 & $\begin{array}{l}50.8 \\
\text { various age groups }\end{array}$ & $\begin{array}{l}\text { Small sample size, } \\
\text { high risk group }\end{array}$ \\
\hline Sinha et al, $1999(20)$ & Central Canadian Arctic & 163 & 67,2 nd year of life & $\begin{array}{l}\text { Small size, } \\
\text { high risk group }\end{array}$ \\
\hline Thomson et al, 2003 (21) & Canada & 1040 & 30 & $\begin{array}{l}\text { Clinical population: } \\
\text { dyspeptic patients }\end{array}$ \\
\hline
\end{tabular}

both intestinal-type and diffuse-type gastric adenocarcinoma (except gastric cardia cancers) and mucosa-associated lymphoid tissue lymphoma.

H pylori has been declared a group 1 carcinogen (12). Most of the nine Bradford Hill criteria (33) for causation have been clearly fulfilled: the strength of the association is established with a relative risk estimated at six-fold (34). In fact, current risk estimates may underestimate risk, because of the high prevalence of $\mathrm{H}$ pylori seropositivity in the older populations the control groups - representing the well-recognized cohort phenomenon (8). The observation of an association between H pylori and gastric cancer has been shown in different populations under different circumstances, hence fulfilling the criterion of consistency (32). Temporality has clearly been demonstrated with seroepidemiological studies (35) and by a recent prospective study conducted in Japan (36). Over an eight-year period, they found that gastric cancer developed in just under $3 \%$ of patients infected with $H$ pylori, while no cases of gastric cancer were observed in the noninfected controls. Biological gradient refers to the presence of a dose-response curve relationship between $H$ pylori infection and gastric cancer. This has not been shown to our knowledge, at least not in humans. The plausibility of an infection, known to cause chronic inflammation as a cause of cancer is certainly acceptable through mechanisms described below, and analogous to chronic viral hepatitis ( $\mathrm{B}$ or $\mathrm{C}$ ) leading to hepatocellular carcinoma. There is also no conflicting information against a causal association between $H$ pylori and gastric cancer, so that the coherence criterion is met.

The criterion specificity requires that a cause lead to a single effect, which is not the case for $\mathrm{H}$ pylori, but it is also not the case for cigarette smoking and lung cancer. In fact, this criterion has been criticized and labelled "useless" (37). As a possible explanation, the effects of $H$ pylori depend on the location of the infection and the inflammation, cell proliferation, and apoptosis this infection generates (38). Antral predominant gastritis has been associated with increased acid secretion and predisposition to duodenal ulcers. In contrast, patients with gastritis involving the acid-producing corpus region of the stomach are at increased risk of developing hypochlorhydria, gastric ulcer, gastric atrophy, intestinal metaplasia and adenocarcinoma (39). Furthermore, an important distinguishing factor of $\mathrm{H}$ pylori strains is the presence of the Cag pathogenicity island (PAI). The Cag PAI is a region of foreign DNA inserted in the bacterial chromosome, which encodes for a type IV secretion system that inserts bacterial proteins into host cells (17). The Cag PAI is a horizontally acquired locus of approximately $40 \mathrm{~kb}$ that contains 31 genes. Infection with $\mathrm{CagA}+\mathrm{H}$ pylori strains is associated with greater cell proliferation without a corresponding increase in apoptosis (39). In certain populations, the presence of infection with strains possessing the Cag PAI is associated with an increased risk of developing atrophic gastritis and gastric cancer (39). In addition, infection of Mongolian gerbils with strains that lack the Cag PAI is associated with a reduction in gastric atrophy (40). However, the exact mechanisms by which products of the Cag PAI promotes carcinogenesis remain unclear.

Gastric cancer incidence is relatively low in contrast to infection rates. Explanatory factors include the fact that: different $H$ pylori strains have different levels of pathogenicity; some people are genetically predisposed to develop gastric cancer; or that gastric cancer risk is contingent on several factors, including the biological interaction between the host and the pathogen. Many studies have described host genetic factors that make family members of gastric cancer cases prone to atrophy, such as HLA-DQA1*0102 or HLA-DQB1*0401 alleles $(41,42)$. Recently, it has been demonstrated that interleukin-1 gene cluster polymorphisms are associated with an increased risk of both hypochlorhydria induced by $\mathrm{H}$ pylori and gastric cancer, suggesting that these host factors may play a role in determining why some individuals infected with $\mathrm{H}$ pylori develop gastric cancer and others do not (43-45).

The final Hill criterion is experimental evidence. While there is good evidence that $\mathrm{H}$ pylori infection is associated with increased cancer risk, no evidence exists demonstrating that treatment of this infection prevents gastric cancer. Decades will be required prior to the availability of convincing results given the natural history of the infection. In addition, recruitment of patients into the placebo arm of such a study is becoming more difficult, if not unethical, given a failure to address a potentially modifiable risk factor in these patients.

Workshop participants agreed that although the sequence of gastric carcinogenesis is not entirely understood, based on the evidence to date $H$ pylori plays an important role, if not the most important role, in gastric carcinogenesis.

\section{Is $H$ pylori screening practical?}

An effective screening program is one in which the test is sensitive, specific and feasible to implement for screening purposes. Presently, there are three screening tests available to detect $H$ pylori: serology, the urea breath test (UBT) and endoscopic biopsy of the gastric mucosa. Workshop participants discussed two key issues regarding these tests: sensitivity and specificity; and asymptomatic versus symptomatic patients.

Participants concluded that the ability of the test to yield a normal result in a high proportion of people who do not have $H$ pylori (ie, specificity) is more important than sensitivity in 
cancer screening. Of the three tests, serological testing is comparatively less expensive to use to diagnose $H$ pylori, and would be more acceptable to patients than endoscopic biopsy. UBT has better sensitivity and specificity than serology. Compared with serology, UBT is of greater value to follow up the success of $\mathrm{H}$ pylori eradication therapy. Most importantly, serology cannot determine 'active' H pylori infection, while UBT can. For population applications, serology may be more appropriate for asymptomatic patients and the UBT for symptomatic individuals.

Endoscopic biopsy is not practical for population screening. Serology or UBT would both be appropriate and practical for this purpose, although a cost effective study comparing UBT with serology in cancer screening would be very beneficial.

\section{Does $\mathbf{H}$ pylori eradication prevent gastric cancer?}

Workshop participants agreed that eradication of $H$ pylori would likely prevent some stomach cancers, provided the intervention comes early enough in the sequence of carcinogenesis. However, further studies are needed to determine the appropriate age at which $H$ pylori screening and eradication should be initiated $(46,47)$.

Triple therapy, or the combination of two antimicrobial agents with a PPI, has been evaluated extensively in the treatment of $\mathrm{H}$ pylori, and shown to produce cure rates for the infection of greater than $80 \%(48,49)$.

Workshop participants discussed the extent to which the eradication of $\mathrm{H}$ pylori will prevent the development of gastric cancer. A number of issues emerged during the discussion, including the paucity of evidence from intervention studies, so far, to say that $H$ pylori eradication will prevent the onset of some gastric cancers. Sung and colleagues (50), however, reported that the progression of gastric atrophy may be prevented following $H$ pylori eradication therapy. However, there are difficulties in the histological interpretation and interobserver variation of gastric atrophy, and some experts feel that gastric cancer is the only outcome of significance. A nonrandomized study conducted in Japan showed a significantly lower rate of gastric cancer recurrence, as well as a reduced progression of atrophic gastritis (51). The results of a more recent prospective study involving the same Japanese group of investigators, with a mean follow-up period of 4.8 years, indicated that $\mathrm{H}$ pylori eradication prevented the development of gastric adenocarcinoma (36). These Japanese studies, although limited in their period of follow-up, represent the strongest evidence to date for the cancer prevention benefits of $\mathrm{H}$ pylori eradication.

\section{Is $H$ pylori eradication practical and safe?}

Although $H$ pylori eradication has been shown to be associated with a decrease in the rates of gastric carcinoma, few concerns about its safety needed to be addressed, mainly antibiotic resistance and gastroesophageal reflux disease (GERD).

The use of antibiotics, mainly metronidazole and clarithromycin, in regimens for the treatment of $H$ pylori is increasing in many countries, including Canada. This increase in the use of antibiotics might precipitate antibiotic resistance in H pylori as well as other bacteria in the host. The prevalence of primary $\mathrm{H}$ pylori resistance in Canada appears to be $18 \%$ to $22 \%$ for metronidazole and less than $4 \%$ for clarithromycin. These rates seem to be consistent across the different regions studied in Canada, but many regions have not been studied (32).

Another concern about the safety of $H$ pylori eradication is the potential association between the cure of the infection and an increase in the risk of GERD. There has been concern that $H$ pylori eradication may be associated with GERD and esophageal cancer. In infected patients with a corpuspredominant gastritis and reduced gastric acid secretion, eradication of $\mathrm{H}$ pylori may promote enhanced secretion of gastric acid, and lead to the development of GERD $(39,52)$. However, this theoretically increased risk is likely small and other studies have shown no worsening or increased risk of developing GERD (53). In fact, some have suggested a reduction of heartburn with $H$ pylori treatment (54-56). Although there is increasing evidence against such concern, further work is required to illuminate possible mechanisms in the evolution of GERD following $H$ pylori eradication before advocating a screen and treat approach to asymptomatic individuals.

In addition to its association with gastric cancer, and despite dropping prevalence of $\mathrm{H}$ pylori-infected ulcer patients in North America, $\mathrm{H}$ pylori is still a major cause of duodenal and gastric ulcers. The lifetime risk of peptic ulcer in a person infected with $\mathrm{H}$ pylori ranges from $3 \%$ in the United States to $25 \%$ in Japan $(57,58)$. Eradication of $H$ pylori drastically lowers the recurrence rates of $\mathrm{H}$ pylori-associated ulcers (59). H pylori eradication has the potential to prevent other chronic diseases such as duodenal ulcer (60). The estimated lifetime risk of $5 \%$ to $15 \%$ for developing peptic ulcer would be eliminated. There is controversy as to whether patients with dyspepsia will benefit from $H$ pylori eradication, but it seems that a small proportion (up to $15 \%$ ) of such patients will also benefit from the treatment $(54,61,62)$.

With few adverse events of therapy, generally, a single course of treatment and high patient compliance to participate in and complete treatment, workshop participants felt that this was a safe and inexpensive intervention compared with other cancer screening interventions. One cost effectiveness study compared screening for $\mathrm{H}$ pylori and treatment of those who were screened positive, with that where there is no screening or treatment of $\mathrm{H}$ pylori. Risk estimates and costs were taken from published studies, and sensitivity analysis was done, because the efficacy of $\mathrm{H}$ pylori therapy to prevent stomach cancer is unknown. The authors concluded that screening and treatment of $\mathrm{H}$ pylori is possibly cost effective in preventing some gastric cancers, especially in high-risk populations (63). Canadian data would yield a similar conclusion, as the only difference in figures from the above American study would be a lower cost of screening, $H$ pylori treatment and cancer treatment.

\section{What are the ethical issues of $H$ pylori eradication to prevent stomach cancer?}

Ethical issues arise from the uncertainty of the evidence in favour of, and against, $H$ pylori eradication. In the absence of strong trial evidence, a program of $\mathrm{H}$ pylori eradication might be too expensive or potentially cause harms that would outweigh its benefits. Such ethical concerns are central to decisions as to whether to pursue a particular avenue of preventative medicine (64).

Decisions must be made in medicine with less than ideal evidence (65) and trade-offs often occur between scientific rigour and therapeutics. Difficulties in mounting conclusive 
trials and the salience of current, albeit less-than-optimal, evidence might advocate in favour of a preventative program for a serious illness. For example, the wish to prevent a specific illness for which current management strategies are inadequate, might lead one to advocate for a proposed promising preventative intervention, even though its effectiveness had yet to be demonstrated (66). Such is the situation for gastric cancer: usually discovered late, treatment is difficult and survival is poor. $44 \%$ to $67 \%$ of patients are diagnosed with advanced disease (metastatic disease either regionally or to distant sites) and their five-year survival is less than $30 \%$. The optimum type of surgery (none of which is simple) and the usefulness of neo-adjuvant treatment are issues that are as yet unanswered (67).

Ethically acceptable decision-making can occur in the absence of a randomized controlled trial, in particular, beneficence, respect for patients, and fairness ought to inform any decision (68) made in balancing an intervention's efficacy with protecting patients from harm. Decisions based on such a review of the existing evidence may be more acceptable if the process to arrive at them is an ethically 'inclusive' one, involving recognized experts as well as generalists and members of the public (69). Absent effective therapy for gastric cancer and given the difficulties in early detection, there is a greater ethical rationale for an effective preventative program for gastric cancer.

\section{CONCLUSIONS}

In the absence of evidence from randomized controlled trials, as well as the absence of other compelling evidence based on long term follow-up, workshop participants did not recommend general population screening at this time for eradication of $\mathrm{H}$ pylori. However, they did recommend a pilot observational study offering screening to informed individuals of a chosen region (see below for detailed description). The discussion also concluded that a randomized controlled trial to eradicate H pylori to prevent stomach cancer is unlikely to be feasible or timely for several reasons. First, given the prevalence of $H$ pylori and rarity of gastric cancer, a randomized controlled trial would require a very large sample size to have sufficient power to measure the effect. Secondly, it is unlikely that patients would freely participate in a control group, since the intervention for $\mathrm{H}$ pylori eradication is time-limited and generally safe. In this light, such a trial itself might be seen as ethically questionable since some patients will be at an increased cancer risk due to a failure to address a modifiable risk factor $(70,71)$. The discussions also concluded that more research is needed into the pathogenesis of gastric cancer. Finally, it is necessary to determine the cost-effectiveness of the $H$ pylori screening method (UBT versus serology) to be used to prevent gastric cancer and the age at which this screen best be performed.

\section{Recommendations}

- The prevalence of H pylori infection in the different regions of Canada should be further characterized. There are some excellent prevalence data in certain regions of Canada, but no national estimates exist, nor are there estimates derived from very large average risk populations anywhere in Canada. In addition, these data should be obtained in relation to age and risk groups.
- Testing for H pylori is high across the country (72) and often serological tests are repeated after treatment. These subsequent tests are often falsely positive. Existing administrative and laboratory databases should be analyzed to determine testing results by individual. For example, this could proceed in Canada based in part on the analysis of provincial lab use data for serology. There is no indication to repeat serology in an individual and hence repeat tests could be refused, thus reducing costs.

- Further studies are needed to measure the pathogenesis of the sequence of carcinogenesis from $\mathrm{H}$ pylori infection. The availability of appropriate animal models could be used to help dissect the interactions between this microbial pathogen and the host. In addition, the $H$ pylori genome is sequenced, serving as a tool to identify bacterial factors that could be involved in gastric carcinogenesis. Proteomics approaches should provide useful information to identify proteins in the pathogen, leading to an understanding of their role in physiological and pathophysiological functions.

- A prospective observational study (a demonstration project) should be implemented in a well-defined geographical area. There is sufficient evidence to justify offering $\mathrm{H}$ pylori screening to properly informed patients in the context of a demonstration project.

Screening would be offered to all adults within specified upper and lower age limits. Special efforts would be made to reach high-risk groups including immigrants from countries with high prevalence of $H$ pylori, persons of low socioeconomic status and aboriginals, as well as individuals with a family history of gastric cancer. Participation in the demonstration project would yield a measure of patient compliance with screening and treatment.

The demonstration project could include:

- A requisition form for serology (as the test of choice for the demonstration project);

- A database (registry) to monitor and evaluate the program, including adverse events such as reactions to the eradication therapy; and

- An evaluation of the costs and benefits of $H$ pylori eradication (incidence of stomach cancer, gastroesophageal reflux disease and peptic ulcer).

The demonstration project could also permit the development of a measure of the number of people that would require $H$ pylori treatment to prevent one case of gastric cancer (number needed to screen). The serology could be done through a single reference laboratory to ensure quality control and data capture. Indeed, the serology might be piggybacked in a multicultural metropolitan area on an annual 


\section{Sullivan et al}

physical examination where blood might be taken for other purposes. A decision-aid for patients, focused on the risks and benefits of screening, could be designed and evaluated in the study. Focus groups with physicians and patients could identify educational needs and compliance issues.
ACKNOWLEDGEMENTS: Funding for the workshop was received from the Canadian Institutes of Health Research, the Canadian Cancer Society, and Cancer Care Ontario. The authors wish to acknowledge the support of Ms. Cathy Cameron throughout the planning and administration of the workshop.

\section{Appendix A - Workshop Participants}

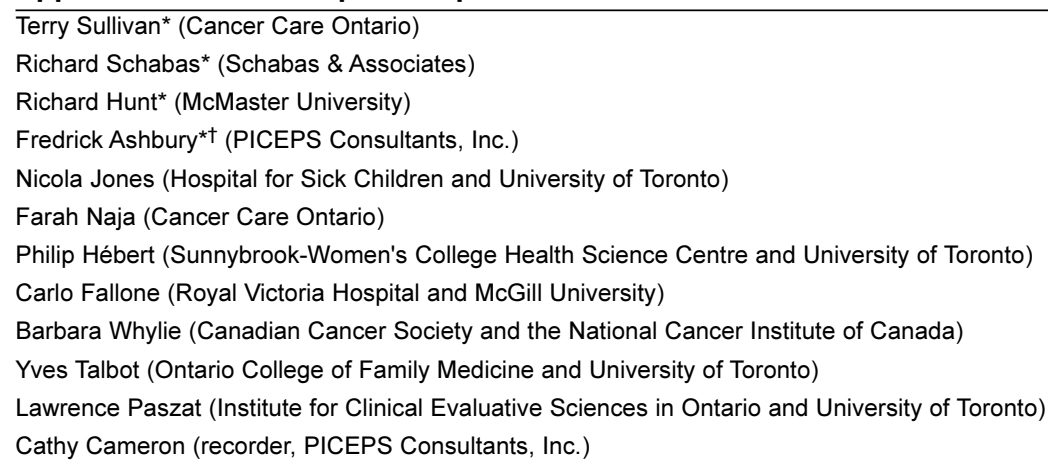

*Member of workshop planning committee; ${ }^{\star}$ Workshop facilitator

\section{Appendix B - Preworkshop Survey}

\begin{tabular}{|c|c|c|c|}
\hline Question & Yes & No & Comments \\
\hline $\begin{array}{l}\text { 1. Is there sufficient evidence that Helicobacter pylori infection causes } \\
\text { gastric cancer? } \\
\text { 2. Is there sufficient evidence that the eradication of } H \text { pylori will } \\
\text { prevent stomach cancer? } \\
\text {-Timing of eradication? } \\
\text { •Attributable risk? } \\
\text { 3. Is there sufficient evidence that the eradication of } H \text { pylori in } \\
\text { asymptomatic people is safe? } \\
\text { •Adenocarcinoma of the esophagus? } \\
\text { •Drug adverse effects? } \\
\text { 4. Is population-level } H \text { pylori eradication a practical consideration? } \\
\text { •Suitable screening test? } \\
\text { •Prevalence of infection? } \\
\text { •Natural history? } \\
\text { •Suitable treatment? } \\
\text { •Cost-benefit? } \\
\text { •High risk groups? } \\
\text { 5. Can we consider population-level H pylori eradication without conducting } \\
\text { a randomized control trial (RCT)? } \\
\text { •What are the logistics of an RCT? } \\
\text { and other important issues? } \\
\text { current state of knowledge? }\end{array}$ & & & \\
\hline
\end{tabular}

\section{REFERENCES}

1. GLOBOCAN 2000: Cancer incidence, mortality and prevalence worldwide, Version 1.0. IARC CancerBase No. 5. Lyon, IARC Press, 2001

2. Canadian Cancer Society. < http://www.cancer.ca $>$ (Version current at March 25, 2004).

3. Lambert R, Guilloux A, Oshima A, et al. Incidence and mortality from stomach cancer in Japan, Slovenia and the USA. Int J Cancer 2002;97:811-18.

4. Alexander HR, Kelsen DG, Tepper JC. Cancer of the stomach.
In: DeVita VT, Hellman S, Rosenberg SA, eds. Cancer: Principles and Practice of Oncology. 5th edn. Philadelphia: Lippincott-Raven, 1997:1021-54.

5. Correa P. Human gastric carcinogenesis: A multistep and multifactorial process. Cancer Research 1992;52:6735-40.

6. Correa P. Helicobacter pylori and gastric cancer: State of the art. Cancer Epidemiol Biomarkers Prev 1996;5:477-81.

7. Sepulveda A, Graham DY. Role of H pylori in gastric carcinogenesis. Gastroenterology Clin 2002;31(2):517-35. 
8. Huang JQ, Sridhar S, Chen Y, Hunt RH. Meta-analysis of the relationship between Helicobacter pylori seropositivity and gastric cancer. Gastroenterology 1998;114:1169-79.

9. Huang JQ, Zheng GF, Sumanac K, Irvine JE, Hunt RH. Metaanalysis of therelationship between Cag A seropositivity and gastric cancer. Gastroenterology 2003;125:1636-44.

10. Bravo LE, van Doom LJ, Realpe JL, Correa P. Virulence-associated genotypes of Helicobacter pylori: Do they explain the African enigma? Am J Gastroenterol 2002;97:2839-42.

11. Huang JQ, Hunt RH. Review article: Helicobacter pylori and gastric cancer - the clinicians' point of view. Ailment Pharmacol Ther 2000;14(Suppl 3):48-54.

12. IARC Working Group on the Evaluation of Carcinogenic Risks to Humans. Helicobacter pylori. Lyon: International Agency for Research on Cancer; 1994:177-240.

13. Malaty HM, El-Kasabany A, Graham DY, et al. Age at acquisition of Helicobacter pylori infection: A follow-up study from infancy to adulthood. The Lancet 2002;359:931-35.

14. Malaty HM, Graham DY, Klein PD, Evans DG, Adam E, Evans DJ Jr. Transmission of Helicobacter pylori infection: Studies in families of healthy individuals. Scand J Gastroenterol 1991;9:927-32.

15. Bamford KB, Bickley J, Collins JS, et al. Helicobacter pylori: Comparison of DNA fingerprints evidence for intrafamilial infection. Gut 1993;34:1348-50.

16. Drumm B, Perez-Perez GI, Blaser MJ, Sherman PM. Intrafamilial clustering of Helicobacter pylori infection. N Engl J Med 1990;322:359-63.

17. Covacci A, Telford JL, Del Guidice G, et al. Helicobacter pylori virulence and genetic geography. Science 1999;284:1328-33.

18. Veldhuyzen van Zanten SJO, Pollak PT, Best LM, et al. Increasing prevalence of Helicobacter pylori infection with age: Continuous risk of infection in adults rather than cohort effect. J Infect Dis 1994;169:434-7.

19. Bernstein CN, McKeown I, Embil JM, et al. Seroprevalence of Helicobacter pylori, incidence of gastric cancer and peptic ulcerassociated hospitalizations in a Canadian Indian population. Dig Dis Sci 1999;44:668-74.

20. Sinha SK, Martin B, Sargent M, et al. Age of acquisition of Helicobacter pylori in a pediatric Canadian First Nations population. Helicobacter 2002;7:76-85

21. Thomson AB, Barkun AN, Armstrong D, et al. The prevalence of clinically significant endoscopic findings in primary care patients with uninvestigated dyspepsia: the Canadian Adult Dyspepsia Empiric Treatment - Prompt Endoscopy (CADET-PE) study. Aliment Pharmacol Ther 2003;17:1481-91.

22. Fischbach LA, Goodman KJ, Feldman M, Aragaki C. Sources of variation of Helicobacter pylori treatment success in adults worldwide: A meta-analysis. Internat J Epidemiol 2002;31:128-39.

23. Lind T, Veldhuyzen van Zanten S, Unge P, et al. Eradication of Helicobacter pylori using one-week triple therapies combining omeprazole with two antimicrobials: The MACH 1 Study. Helicobacter 1996;138-44.

24. Hunt R, Thomson ABR, Consensus Conference Participants. Canadian Helicobacter pylori Consensus Conference. Can J Gastroenterol 1998;12:31-41.

25. Hunt RH, Fallone CA, Thomson ABR, Canadian Helicobacter Study Group. Canadian Helicobacter pylori Consensus Conference update: Infections in adults. Can J Gastroenterol 1999;13:213-7.

26. Chiba N, Marshall CP. Omeprazole once or twice daily with clarithromycin and metronidazole for Helicobacter pylori. Can J Gastroenterol 2000;14:27-31.

27. Chiba N. Omeprazole and clarithromycin with and without metronidazole for the eradication of Helicobacter pylori. Am J Gastroenterol 1996;91:2139-43.

28. Veldhuyzen van Zanten SJO, Lauritsen K, Delchier JC, et al. One-week triple therapy with esomeprazole provides effective eradication of Helicobacter pylori in duodenal ulcer disease. Aliment Pharmacol Ther 2000;14:1605-11.

29. Suerbaum S, Michetti P. Helicobacter pylori infection. N Engl J Med 2002;347:1175-86.

30. Hunt RH, Smaill FM, Fallone CA, Sherman PM, Veldhuyzan van Zanten SJO, Thomson ABR. Implications of antibiotic resistance in the management of Helicobacter pylori infection: Canadian Helicobacter Study Group. Can J Gastroenterol 2000;14:862-68.

31. Veldhuyzen van Zanten SJO, Hunt R, Cockeram A, et al. Adding once-daily omeprazole $20 \mathrm{mg}$ to metronidazole/amoxicillin treatment for Helicobacter pylori gastritis: A randomized, doubleblind trial showing the importance of metronidazole resistance. Am J Gastroenterol 1998;93:5-10.

32. Fallone CA. Epidemiology of antibiotic resistance of Helicobacter pylori in Canada. Can J Gastroenterol 2000;14:879-82.

33. Bradford-Hill A. The environment and disease: Association or causation? Proc R Soc Med 1966;58:295.

34. An international association between Helicobacter pylori infection and gastric cancer. The EUROGAST study group. Lancet 1993;341:1359-62.

35. Parsonnet J, Friedman GD, Vandersteen DP, et al. Helicobacter pylori infection and the risk of gastric carcinoma. N Engl J Med 1991;325:1127-31.

36. Uemura N, Okamoto S, Yamamoto S, et al. Helicobacter pylori infection and the development of gastric cancer. N Engl J Med 2001;345:784-9.

37. Rothman KJ, Greenland S. Causation and casual influence. In: Rothman KJ, Greenland S, eds. Modern Epidemiology, 2nd edn. New York: Lippincott Williams \& Wilkins, 1998:7-28.

38. Shirin H, Moss SF. Helicobacter pylori induced apoptosis. Gut 1998;43:592-94.

39. Peek RM Jr, Blaser MJ. Helicobacter pylori and gastrointestinal tract cancers. Nature Rev Cancer 2002;2:28-37.

40. Peek RM Jr, Wirth HP, Moss SF, et al. Helicobacter pylori alters gastric epithelial cell cycle events and gastrin secretion in Mongolian gerbils. Gastroenterology 2000; 118:48-59.

41. Azuma T, Ito S, Sato F, et al. The role of the HLA-DQA1 gene in resistance to atrophic gastritis and gastric adenocarcinoma induced by Helicobacter pylori infection. Cancer 1998;82:1013-8.

42. Sakai T, Aoyama N, Satonaka K, et al. HLA-DQB1 locus and the development of atrophic gastritis with Helicobacter pylori infection. J Gastroenterol 1999;34(Suppl 11):24-7.

43. El-Omar EM, Carrington M, Chow WH, et al. Interleukin-1 polymorphisms associated with increased risk of gastric cancer. Nature 2000;404:398-402.

44. Machado JC, Pharoah P, Sousa S, et al. Interleukin-1B and interleukin-1RN polymorphism are associated with increased risk of gastric carcinoma. Gastroenterology 2001;121:823-9.

45. El-Omar EM. The importance of interleukin-1[beta] in Helicobacter pylori-associated disease. Gut 2001;48:743-7.

46. Imrie C, Rowland M, Bourke B, Drumm B. Is Helicobacter pylori infection in childhood a risk factor for gastric cancer? Pediatrics 2001;107:373-80.

47. Fallone CA, Barkun AN, Halwani F. Does Helicobacter pylori eradication prevent gastric cancer? DigLiver Dis 2001;33: 803-4.

48. Laheji RJ, Rossum LG, Jansen JB, Straatman H, Berbeek AL. Evaluation of treatment regimens to cure Helicobacter pylori infection - a meta-analysis. Ailment Pharmacol Ther 1999;13:857-64.

49. Hunt RH, Fallone CA, Thomson ABR, Canadian Helicobacter Study Group. Canadian Helicobacter pylori Consensus Conference update: Infections in adults. Can J Gastroenterol 1999;13:213-7.

50. Sung JJY, Lin SR, Ching JYL, et al. Atrophy and intestinal metaplasia one year after cure of $H$ pylori infection: A prospective randomized study. Gastroenterology 2000;119:7-14.

51. Uemura N, Mukai T, Okamoto S, et al. Effect of Helicobacter pylori eradication on subsequent development of cancer after endoscopic resection of early gastric cancer. Cancer Epidemiol Biomarkers Prev 1997;6:639-42.

52. Fallone CA, Barkun AN, Friedman G, et al. Is Helicobacter pylori eradication associated with gastro-esophageal reflux disease? Am J Gastroenterol 2000;95:914-20.

53. Moayyedi P, Bardhan C, Young L, Dixon MF, Brown L, Axon AT. Helicobacter pylori eradication does not exacerbate reflux symptoms in gastroesophageal reflux disease. Gastroenterology 2001;121:1120-6.

54. Chiba N, van Zanten SJV, Sinclair P, Ferguson RA, Escobedo S, Grace E. Treating Helicobacter pylori infection in primary care patients with uninvestigated dyspepsia: The Canadian adult dyspepsia empiric treatment-Helicobacter pylori positive (CADET-Hp) randomized controlled trial. BMJ 2002;324:1-7.

55. Wildner-Christensen M, Hansen JM, Schaffalitzky de Muckadell OB. Rates of dyspepsia one year after Helicobacter pylori screening and eradication in a Danish population. Gastroenterology 2003;125:372-9.

56. Moayyedi P, Feltbower R, Brown J, et al. Effect of population screening and treatment for Helicobacter pylori on dyspepsia and 


\section{Sullivan et al}

quality of life in the community: A randomized controlled trial. Lancet 2000;355:1665-9.

57. Schlemper RJ, van der Werf SD, Biemond I, Lamers CB. Seroepidemiology of gastritis in Japanese and Dutch male employees with and without ulcer disease. Eur J Gastroenterol Hepatol 1996;8:33-9.

58. Feldman RA. Epidemiologic observations and open questions about disease and infection caused by Helicobacter pylori. In: Achtman M, Suerbaum S, eds. Helicobacter pylori: Molecular and Cellular Biology. Wymondham, United Kingdom: Horizon Scientific Press, 2001:29-51.

59. Marshall BJ, Goodwin CS, Warren JR, et al. Prospective doubleblind trial of duodenal ulcer relapse after eradication of Campylobacter pylori. Lancet 1988;2:1437-42.

60. Hunt RH, Fallone CA, Veldhuyzan van Zanten SJO, Sherman P, Smail F, Thomson ABR. Risks and benefits of Helicobacter pylori eradication - current status. Can J Gastroenterol 2002;16:57-62.

61. Moayyedi P, Soo S, Deeks J, et al. Systematic review and economic evaluation of Helicobacter pylori eradication for nonulcer dyspepsia. BMJ 2000;321:659-64.

62. McColl K, Murray L, El-Omar E, et al. Symptomatic benefit from eradicating Helicobacter pylori infection in patients with nonulcer dyspepsia. N Engl J Med 1998;339:1869-74.

63. Parsonnet J, Harris RA, Hack HM, Owens DK. Modeling costeffectiveness of Helicobacter pylori screening to prevent gastric cancer: A mandate for clinical trials. Lancet 1996;348:150-4.
64. Roper W, Thacker S. Doing good before there is harm. In: Warren K, Mosteller F, eds. Doing More Good than Harm: The Evaluation of Health Care Interventions. New York; Annals of NY Academy of Sciences, 1993:33-40.

65. Sackett D, Strauss S, Richardson W, Rosenberg W, Haynes RB. Evidence-based Medicine: How to Practice \& How to Teach EBM, 2nd edn. London: Churchill Livingstone, 2000:7-8,105ff.

66. Brody B. Ethical Issues in Drug Testing, Approval, and Pricing: The Clot-Dissolving Drugs. New York: OUP, 1995:170-3.

67. Hohenberger P, Gretshel S. Gastric cancer. Lancet 2003;362:305-15.

68. Hébert PC. Doing Right: A Practical Guide to Ethics for Physicians and Medical Trainees. Toronto: OUP, 1996:15.

69. Pfeiffer N. Informed consent in medical research: The consumers' view. In: Doyal L, Tobias J, eds. Informed Consent in Medical Research. London: BMJ Books, 2001:283-90.

70. Phillips P. Mixed response to new PSA screening study. JAMA 1998;280:8-9.

71. Lessard v Labrie, et al. In: Gouvain H, Rochette L. Court of Appeal confirms the jurisdiction of the Discipline Committee of the CHUQ. < http://www.laverydebilly.com/pdf/bulletins/011203a.pdf> (Version current at March 30, 2004).

72. Sy R, Lee S, Veldhuyzen van Zanten SJO. Dramatic increase in the use of Helicobacter pylori (HP) serology across Canada despite lack of proof of efficacy of a noninvasive test and treat strategy. Can J Gastroenterol 1999;13(Suppl B):152B. 


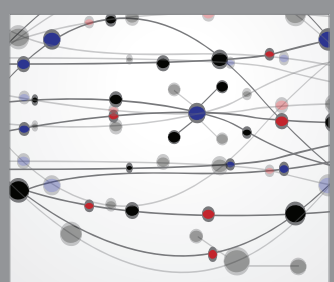

The Scientific World Journal
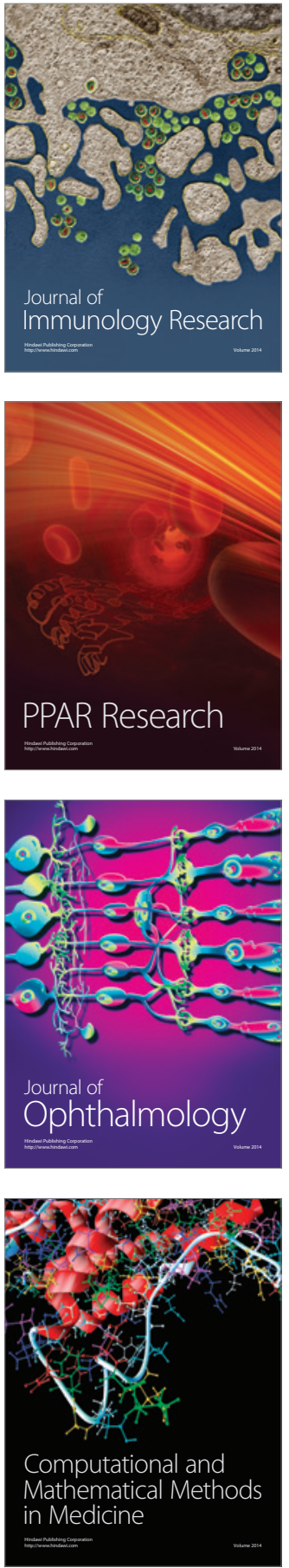

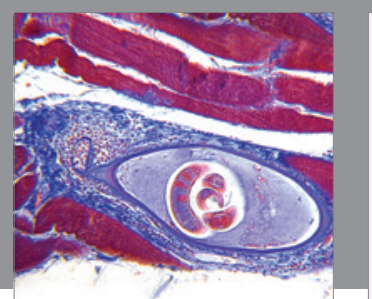

Gastroenterology Research and Practice

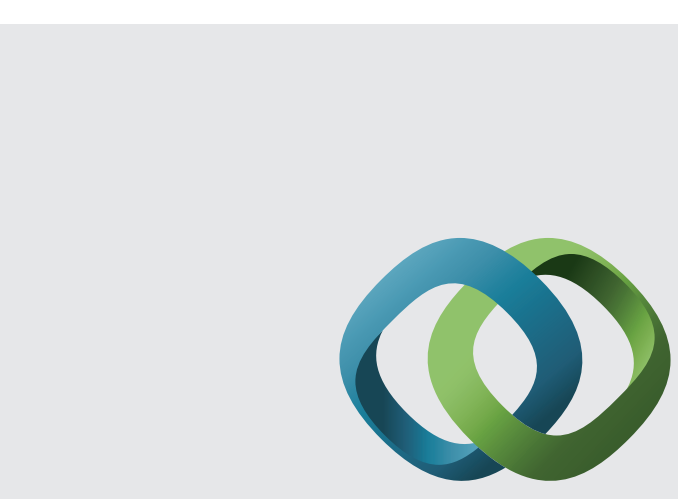

\section{Hindawi}

Submit your manuscripts at

http://www.hindawi.com
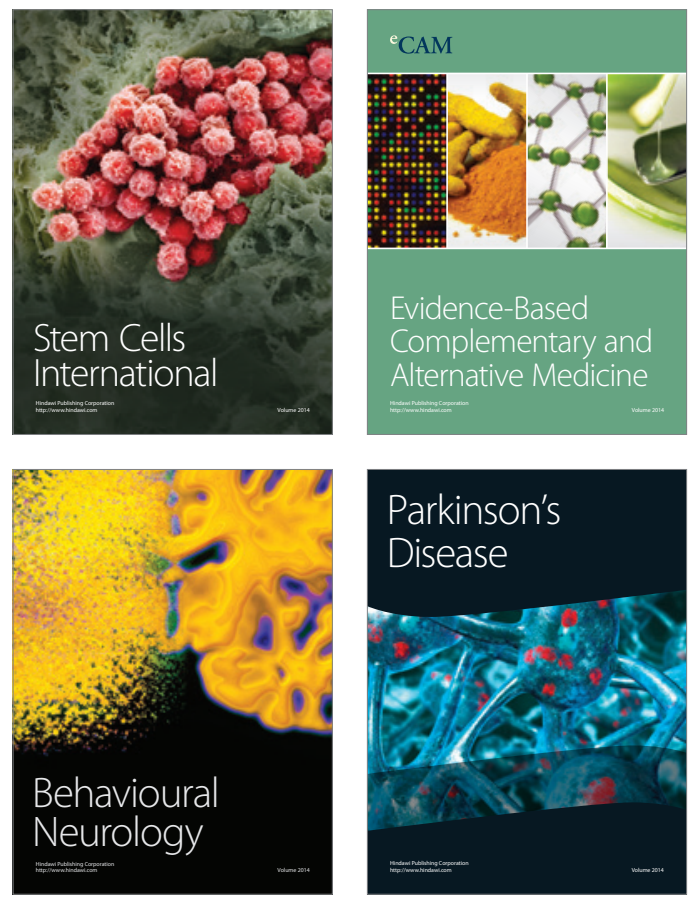
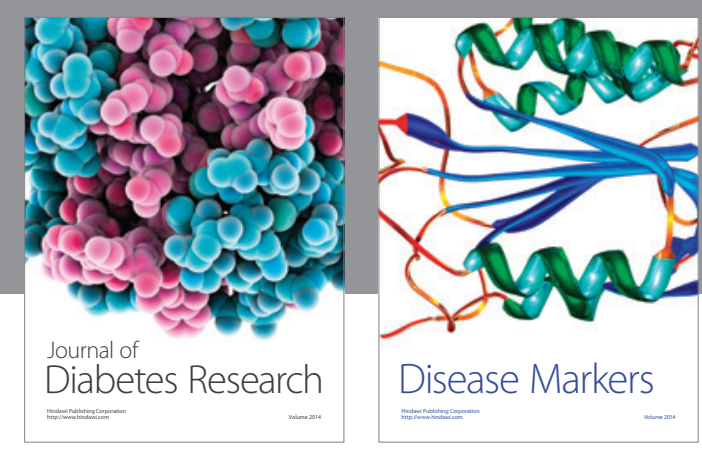

Disease Markers
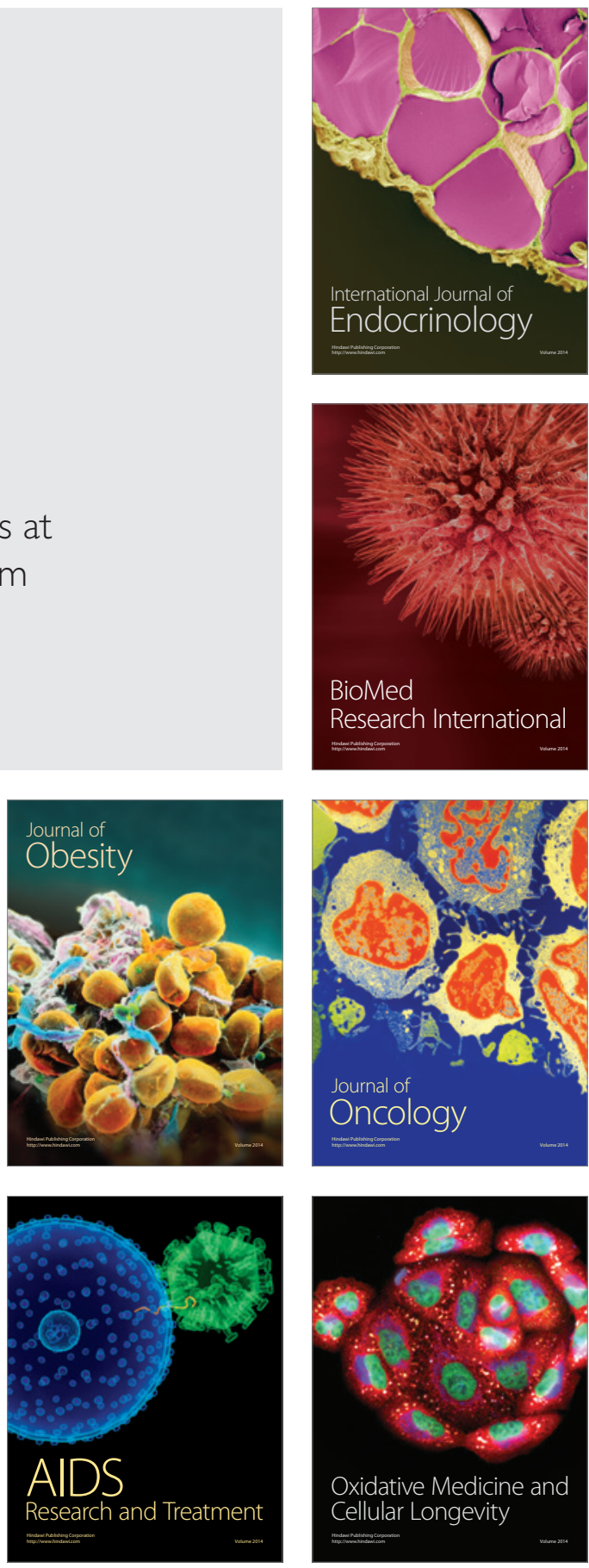